\title{
1. Introduction to Neoliberal Social Justice
}

What policies are most aligned with John Rawls' (1999 [1971]) theory of distributive justice? More broadly, what political institutions can ameliorate the arbitrary socio-economic inequalities that are pervasive in contemporary societies (Novak, 2018)? These questions have grown in urgency in recent years amongst both scholars and policymakers. This is due, in part, to increases in income and wealth inequality within nations throughout the developed world (Saez, 2012; Hills et al., 2013; Piketty, 2014).

A range of scholars have addressed this question of what Rawlsian public policies and political institutions should look like. Rawls is typically associated with support for social democratic (Barry, 1973), sometimes more radical egalitarian economic institutions (Chambers, 2012; Edmundson, 2017). Martin O'Neill and Thad Williamson (2012) take inspiration from Rawls' endorsement of James Meade's (2012 [1964]) notion of a property-owning democracy (POD). This POD comprises three key features:

1. state ownership of substantial capital assets,

2. direct state provision of public goods, and

3. a private-property economy where private capital is systematically taxed to prevent ownership from becoming concentrated.

Some classical liberal scholars argue that Rawls' framework, though not Rawls' stated views, points towards a more limited state and a wider role for individual economic liberty (Shapiro, 1991; Buchanan, 2000 [1975]; Gaus, 2010). John Tomasi (2012) grounds his case for economic liberty in the Rawlsian attitude that institutions should foster responsible self-authorship and allow for the formation and pursuit of an individual conception of the good. He argues that democratic citizens would endorse 'thick' economic liberties and a regime along the lines of 'market democracy' rather than a socialist regime or POD.

A thread in this debate is the question of whether 'capitalism' produces wider gaps in income and wealth or whether such a tendency is due to contingent factors. Does 'capitalism' produce wider wealth gaps by definition (Krouse and McPherson, 1988), constitution (Piketty, 2014), or general tendencies in technological development (Meade, 2012 [1964])? Or do contingent 
factors such as the inclusivity of institutions (Acemoglu and Robinson, 2015) and the amount of rent-seeking (Baker, 2015), and cronyism (Zingales, 2012) within a particular set of institutions account for this gap? If the explanation relates to inevitable features of capitalism, then Rawls' principles of justice point towards radical alternatives to capitalism or substantial, pro-active state intervention in economic activity to compensate for these innate tendencies of capitalism. If the explanation is more contingent, then it may be possible to establish a range of economic liberties within a framework of capitalist institutions that, taken as a whole, help meet the requirements of justice as fairness according to Rawls' framework.

\section{POLITICAL REALISM}

Part of this debate hinges on philosophical questions about what is necessary for moral autonomy. Other elements, however, relate to the plausibility that a regime would lead to desirable outcomes. For example, some of Tomasi's critics argue that even though economic liberty could be morally valuable in some respects, it cannot be specified in a way that will not impact negatively on more fundamental liberties. Economic liberty that is protected from state intervention will lead to wealth inequality. Wealth inequality will translate into political inequality where the rich have disproportionate influence on formal democratic decisions. A key criticism is that it is unrealistic to expect the institutions of individual economic liberty to satisfy the requirements of justice as fairness.

This issue of 'realism' has grown in importance in political theory (Schmidtz, 2016). This has happened in parallel with the debate about the policy and institutional implications of Rawls' approach. 'Realism' is a diverse movement, with inspirations drawn from a range of sources including Thucydides, Machiavelli, Hobbes, Marx, Weber, Nietzsche and Williams. A common, if not essential, aspect of the method rejects the notion that political theory is a subset of applied ethics, and instead represents its own domain, where more minimal concerns of maintaining social order and reducing conflict override other social goods.

Through this lens, theorists such as Geuss (2008) criticise the Rawlsian approach for failing to appreciate fully the coercive nature of politics and the implausibility of shared agreement on fundamental ethical principles. For some realists, Rawls' conception of the problem of political philosophy as being one of reconciling reasonable pluralism in a community is not a real political problem (if only it were!). The real political problem, and one that conflict hinges on, is the ability for a society to coordinate and cooperate despite a great deal of deep disagreement on basic values and interests (Cowen, 2017; Sleat, 2016; Sabl, 2017). This criticism is itself subject to reasonable 
contestation. Thomas (2015) points out that realists often fail to acknowledge Rawls' concerns with realism and his related discussion of institutions.

Parijs (2011) makes an explicit attempt to combine some realistic concerns about political behaviour with Rawlsian aspirations. Parijs acknowledges that democratic decision-making, in the real world of vote-hungry parties trying to gain power, cannot be expected to track the demands of justice as fairness. He focuses, as an example, on the 'grey vote', the disproportionate influence of elderly electors on public policy, especially pension provision, that risks committing a significant injustice between the generations. Parijs suggests tweaking the democratic process, even suggesting altering the rules of the vote franchise, to correct for these biases. His point is that, given the influence of self-interest in real-world politics, we cannot design constitutions purely on principles, for example, that seem the most democratic (cf. Brennan, 2016). They must be established partly with an eye on the realistic economic and social consequences of the resulting competition for votes and policies within those rules. The problem of realism has a bite for both market and democratic processes.

This revived interest in the realistic consequences of institutions opens up a dimension in the debate between classical liberal and high liberal approaches to Rawlsian public policy (Freeman, 2001). A theoretical realism, on my account, is important, not to undercut idealistic theorising but because it is a pre-requisite for linking normative theory with real politics and empirical social science. Without realistic assumptions, normative judgements regarding policies within existing political regimes and their resulting social outcomes may be skewed and unhelpful.

This context prompts my central question:

- What are the policy implications of Rawls' theory of justice as fairness if we introduce realistic assumptions about human behaviour and social theory?

My answer is that the policies of a classical liberal or neoliberal democracy, including the constitutional protection of commercial activity, are commendable. We have strong reasons to believe that radical alternatives so far proposed, including liberal socialism and POD, will perform worse at achieving justice in realistic circumstances. Accepting this does not mean losing critical features of the Rawlsian framework. Rather the case for liberal democracy and capitalism follows from appropriately extrapolating Rawls' principles with an updated account of political economy that reflects recent historical experience. The case can be made in line with Rawls' notion of public reason. Acknowledging the advantages of existing liberal democracies does not mean we cannot do better. The best performing liberal democracies have sophisticated policies 
aimed at helping the disadvantaged. Further reforms that take the challenge of sociability seriously have the potential to dramatically expand the scope of human cooperation and sympathy. There are ideas from POD that can be integrated into constitutional liberal democracy.

\section{BASIC LIBERTIES, PERSONAL AND ECONOMIC}

What is at stake between classical liberalism and the high liberal (or liberal egalitarian) Rawlsian approach? It is not so much a disagreement about a state's size or role in providing public goods, or a given distribution of income and wealth. Nor is it about a precise scheme or extent of taxation. Liberal egalitarians and classical liberals certainly approach these questions differently and are likely to come up with different answers. However, plenty of liberal egalitarians endorse market provision of a wide variety of goods and services (Freeman, 2001, p.117). Meanwhile, few classical liberals rule out state provision for certain goods nor kinds of taxation. Buchanan, for example, is a strident classical liberal who, nevertheless, endorses tax policies specifically aimed at reducing wealth concentration (Buchanan, 1976; Buchanan and Congleton, 2003 [1998]; Berggren, 2013). What is at stake, rather, is whether a set of individual economic liberties should be a part of the basic structure of a liberal political community (Zwolinski, 2008). These liberties amount to the right to engage in a wide range of voluntary contracts as well as acquire and possess productive assets, in addition to personal property.

Rawls distinguishes a right to personal property and productive property. Most individual economic liberties are not part of his conception of the basic structure. This does not rule out the inclusion of markets or market-like mechanisms in an economic system, but means that the resulting principles of justice are ambivalent between private-property and socialist economic regimes (Rawls, 1999, p.240). As a result, economic liberties do not receive similar constitutional protections as civil liberties, such as rights to freedom of speech, association, political participation and the practice of religion. It is this conclusion to which many scholars hailing from a classical liberal tradition object. Tomasi (2012) argues that democratic citizens in the original position would select principles which offer constitutional protections to individual choice in market interactions.

\section{RAWLSIAN NEOCLASSICAL ECONOMIC THOUGHT AND THE CATALLACTIC ALTERNATIVE}

My own approach is prompted by this distinction between civil and economic liberty, as well as Rawls' ambivalence between private-property and socialist regimes. This ambivalence is grounded in an unrealistic conceptualisation of 
an economy as a complete 'system' and the economic problem as the allocation of scarce resources between alternative ends (Rawls, 1999, p.234). As Buchanan (1964) points out, this 'allocative' model treats the economic system as a single unit, traditionally a metaphorical Robinson Crusoe figure (Evans, 2010 , p.5). The economic problem is essentially one of calculation: the political community, as a social agent, works out how to allocate given resources to a given range of ends in the most efficient way possible. The model of perfect competition is what explains the allocative efficiency of markets on this account. In a market where there are enough buyers and sellers, and everyone has perfect information, competitive prices will reflect their marginal products.

Gauthier (1986, p.89) explains that in a perfectly competitive market, an individual could act as if she were purely self-interested with absolute confidence that her behaviour would nevertheless produce socially efficient outcomes; though this is not necessarily, as Rawls (1999, p.62) notes, a just outcome. But perfect competition is unrealistic. It is rarely instantiated even for many private goods where information asymmetries are pervasive. On this account, perfect competition models are irrelevant when faced with externalities, where the social costs of producing a good are not reflected in the price, and public goods, where the benefits of production cannot be excluded from free riders. In these cases, state allocation can produce efficient outcomes because it can account for the full social costs of production and compel everyone to contribute fairly.

Because available resources and their productive ends are already given on this perfect competition account, the calculative task of the market economy is also relatively mundane. A variety of institutional regimes can produce efficient allocations. While entrepreneurs carry out the task of allocating resources under a private-property regime, the role could equally be carried out by managers of state-owned or worker-owned firms (Meade, 1945). The main attraction of private-property markets is their convenient way of dividing up this enormous calculative task. In addition, the prices do not only represent information but are also an incentive for a self-interested actor to pursue the most efficient allocation. However, this turns out to be relatively faint praise. On the perfect competition account, there is a wide range of economic activities that private-property markets simply cannot do, and nothing, in principle, that socialist alternatives could not do so long as incentives are handled in some way that simulates private markets.

The result is that Rawls' description of economic activity can read strangely lacking in agency:

[C]ompetitive prices select the goods to be produced and allocate resources to their production in such a manner that there is no way to improve upon either the choice 
of productive methods by firms, or the distribution of goods that arises from the purchases of households. (Rawls, 1999, p.240)

By using this allocative conception of political economy, Rawls subtly rules out the likelihood of conceiving economic liberty as a site of moral development (Cowen, 2021).

Rawls uses this economic theory when developing the institutional implications of justice as fairness. But it could have been otherwise. An alternative conception of an economy is as exchange activity between individuals, or catallaxy (Mises, 1998 [1949], p.233). On this account, knowledge of available resources and possible uses never exists prior to trade, and thus perfect competition is an unrealistic baseline against which to assess market conditions. The primary economic problem is that the knowledge necessary for beneficial cooperative production is dispersed across a whole community (Hayek, 1945, 2014 [1968]; Lavoie, 1986). The puzzle is how individuals in some institutional circumstances, despite their manifest ignorance, manage to coordinate to produce socially desirable outcomes. All this in the absence of an omniscient intelligence that would be necessary to produce a perfectly efficient allocation of resources.

On this alternative account, pricing information is not an input into a calculation but is discovered through trial and error learning, with feedback provided by the realisation of profit and loss. In a private-property market system, economic actors who decide to take on an entrepreneurial role generate this information. They become alert to 'unexploited opportunities' (Kirzner, 2013 [1973], p.33), including resources that are currently under-valued, as well as unmet needs in the community. Rather than accepting all prices as given, entrepreneurs use their personal knowledge that is often local (specific to time and place) and tacit (not easy to communicate through speech or text) to discover otherwise scarce resources and convey them to valuable use (Hayek, 1945, 2014 [1968]). The resulting price differential generates a profit for the entrepreneur. It also reveals an opportunity (or, as it can now be conceived through a neoclassical lens, an 'inefficiency') for other economic actors to exploit.

By discovering and conveying resources and assets to more valuable uses, entrepreneurs bid up the prices of goods used in their chosen production processes, thus closing the gap between their actual prices and their theoretical equilibrium price. However, there are also continuous sources of disequilibrium, including changes in relative scarcities of resources, and the disruption of new goods, technologies and production processes being introduced by other economic actors. On this account, perfect competition and competitive equilibrium are only ever explanatory ideals that we should not expect to 
observe in practice. Competition is never perfect but tends to push prices in the direction of equilibrium.

Competitive markets, on this account, are an example of a spontaneous order (Menger, 1985 [1883], p.146; D’Amico, 2015), where autonomous actors carry out their own plans within a framework of established rules with the aggregate result of producing socially desirable, though not assuredly just, outcomes. Hence, the use of perfect competition as an explanatory ideal type, and even as a simplified model of dynamic contestable markets in the real world, is often justified. However, this model relies on an assumption that an institutional framework already exists that permits the discovery of the necessary knowledge for economic calculation.

It is fruitful to consider Rawls' theory alongside this alternative catallactic understanding of economic activity as part of the basic facts of social theory (Rawls, 1999, p.109). The catallactic approach aligns more closely with the Rawlsian understanding of a political community composed of individual free and equal citizens engaging in an exchange of rights and duties in the form of a social contract. Thus, it is more in keeping with Rawlsian methodological and moral individualism (Kukathas and Pettit, 1990, pp.11-12). For it to be valuable to respect the 'separateness of persons' (which makes the Rawlsian approach distinct from utilitarianism), it must be the case that persons are ontologically separate entities in some relevant sense in the real world. Hence, the facts of social theory should reflect this assumption. This does not rule out significant collective endeavours and appropriate state intervention, but it does suggest that such activity needs to be aligned, in the final analysis, with the knowledge and activity of individuals.

Social aggregates, whether states, firms, households or markets, are necessarily composed of individuals and their interactions with each other. They are both the morally relevant beneficiaries of, and actual participants in, socially cooperative production. Without this adjustment to the facts of social theory, as Schmidtz (2005, p.170) points out, Rawls is left conceiving of the separateness of persons not as producers of goods, but only as consumers of goods.

\section{A RAWLSIAN FRAMEWORK THROUGH THE LENS OF ROBUST POLITICAL ECONOMY}

This book develops the implications of Rawlsian public policy through the lens of Robust Political Economy (RPE). An RPE approach contends that institutions aiming at human welfare should be capable of functioning in the presence of realistic challenges that are significant features of human political and social life, namely imperfect knowledge, bounded rationality and opportunistic behaviour (Pennington, 2011). When considered as a purely scholarly enterprise, some useful concepts and intuitions can be adumbrated without these 
robustness considerations. However, when informing effective public policy, these features of social life become much weightier considerations. This means that institutions commendable in certain important respects are, nevertheless, likely to fail in their aims when applied to the real world. Pennington argues that the classical liberal minimal state is likely to be the most successful at meeting the test of robustness but the RPE approach is an open-ended research agenda, so is open to alternative answers (Cowen, 2016).

The RPE perspective shares substantial overlap with both the Rawlsian approach and political realism (Cowen, 2017). It focuses on how institutions cope with two key problems: imperfect, dispersed knowledge and self-interested motivation (Pennington, 2011, p.18). The research programmes of two related theorists in 'catallactic' political economy, F.A. Hayek and James Buchanan, are what inspire these two questions. Of these two theorists, Buchanan has the most immediate parallels with Rawls. Both participated in reviving the social contract tradition in political theory (Meadowcroft, 2014). They focus on the importance of constitutional design and have a normative commitment to the principle of unanimous agreement as legitimising political institutions:

In their different ways, Rawls, Buchanan, and their followers have sought to combine insights derived from modern social science with some core moral precepts in order to discern the requirements of a just constitution and to build this into various schemes for constitutional design. (Pennington, 2015, p.464)

At the same time, Buchanan presents a political realist position. His inspiration overlaps with realists in political theory, referencing in particular Machiavelli and Hobbes (Buchanan and Tullock, 1999 [1962]; Buchanan, 2000 [1975], 2001, p.46). In rejecting the allocative conception of the economic problem, Buchanan also contributes to a more realistic account of economic and political activity: one that traces back to individual behaviour and interaction (Buchanan, 1999 [1969]).

Hayek is the key exponent of the challenge of dispersed knowledge and its resulting constraints on the efficacy of political intervention (Trantidis and Cowen, 2020; Cowen, 2020a). Unlike Buchanan and Rawls, Hayek (2011 [1960], p.118) is not a social contract theorist, and was a famous critic of even the notion of 'social justice' (Lister, 2013). He nevertheless acknowledged that justice is an important criterion for legitimising formal political institutions. His criticisms of social justice do not apply directly to the Rawlsian framework because Rawls distinguishes between a basic structure where justice applies and the rest of civil society:

there unquestionably also exists a genuine problem of justice in connection with the deliberate design of political institutions, the problem to which Professor John 
Rawls has recently devoted an important book. The fact which I regret and regard as confusing is merely that in this connection he employs the term 'social justice'. (Hayek, 1976, p.100)

Hayek quotes Rawls' explanation of justice applying not to 'specific systems or distributions of desired things' (1976, p.100) but as applying to constraints on a basic structure. Of course, Hayek and Rawls disagree dramatically on the contours of that basic structure and the actual rules and institutions of a basic structure, but this need not necessarily reflect a fundamental conceptual, or even normative, difference (Cowen, 2020b, p.15).

Hayek and Rawls share some common ground on the key problems that political theory faces. Rawls tries to deal with what we could classify as a 'knowledge problem': the challenge of moral disagreement arising out of imperfect judgements even amongst reasonable people. Rawls' hope is to establish the 'fair terms of social cooperation between citizens regarded as free and equal' for a society 'marked by a diversity of opposing and irreconcilable religious, philosophical, and moral doctrines' some of which are 'perfectly reasonable' (Rawls, 2005 [1993], pp.3-4). In other words, while there may be a 'true' comprehensive doctrine, human beings lack the capacity to agree on it. Politics must reckon with that lack of agreement given how deeply held these differing beliefs are.

Hayek and the RPE framework take this problem of agreement on justice to be but one facet of a much broader knowledge problem (Pennington, 2011, p.6), one that includes abstract principles but also disagreement about more mundane questions about the effectiveness and morality of public policies, cultural practices and even personal conduct. Institutions must be able to deal with 'the inevitable ignorance of all of us concerning a great many of the factors on which the achievement of our ends and welfare depend' (Hayek, 2011, p.80).

Both Rawlsian and RPE approaches make use of comparative analysis. For Rawls, his procedure for identifying principles of justice and engaging in reflective equilibrium involves representative agents reasoning back and forth between various alternative conceptions, in order to see which are most plausibly compatible with our intuitions and concrete problems (Daniels, 1979; Kukathas and Pettit, 1990, p.8). The principles of justice are not deduced from axioms but argued to be the ones that would be selected from a menu of plausible options. RPE, in contrast to economic theory that concentrates on developing insights with mathematical tractability, is concerned with the comparative performance of institutions given imperfect, human actors (Pennington, 2011, p.2; Garnett, 2014, p.44). Both projects aim at a form of realism and both use comparative approaches to get there.

Despite these links, Pennington's approach rejects rapprochement between Rawlsian approaches to legitimising a social order and his approach to RPE. 
For Pennington, the knowledge problem undercuts the epistemic position from which agents could successfully come to agreement in the original position, or a constitutional choice situation:

[T]he Rawlsian method of trying to establish an impartial evaluation of social rules and institutions assumes away the very conditions that require the need for social rules and institutions in the first place. Fully idealized rationality of the sort exhibited by actors behind the veil of ignorance implies that people can see through costlessly and instantaneously all the consequences of their beliefs. The model also assumes that everyone is equally rational, similarly situated, and convinced by the same arguments ... (Pennington, 2015, p.483)

Pennington does not offer an explicit alternative normative standpoint to justice as fairness. He sets out the conditions under which institutional performance should be judged. He does not offer specific criteria for what best 'performance' entails. Implicitly, the overarching aims of these institutions appear to be the reduction of conflict, social order and a 'weak utilitarianism' (Pennington, 2015, p.484). Other proponents of classical liberal institutions take a more explicitly utilitarian standpoint (Epstein, 1995).

A problem with Pennington's approach is that it takes a 'thin' goal of social coordination to be a presumed shared goal. Without an explicit normative standpoint, there is little to say in response to critics who prefer institutions that foster conflict. They could be rendered 'well-performing' on those perverse grounds (Cowen, 2018). Furthermore, even if we accept the reduction of social conflict as a shared goal, it is not clear that a minimal state is necessarily the most robust form of governance for maintaining a sustainable social order or even protecting individual liberty (Taylor and Crampton, 2009). It could be unstable compared with various alternatives, such as social democracy (Alves and Meadowcroft, 2013).

There is a potential alignment between Rawls' concerns for the disadvantaged and Pennington's focus on institutional robustness. In both cases, there is a deliberate disproportionate focus on worst-case scenarios at the expense of how humans may thrive in best-case scenarios or in more ideal conditions. Why is that? Some conditions of robustness, despite being pessimistic, are also realistic. The suffering caused by institutional failings, such as death, fear and privation weigh more heavily than the parallel possibilities of greater satisfaction of human desires and higher goals. There is an epistemic element: it is easier for us to agree what bad outcomes look like, and so finding practical agreement on improving the positions of the relatively disadvantaged might be easier than some other criterion such as average utility (Rawls, 1974, p.143).

It also reflects a conception of justice that is ameliorative: working out the minimum of what we can guarantee to each other. Buchanan and Faith (1980) argue that bargaining agents, even with knowledge of their personal positions, 
could converge on distributive principles of maximin that are remarkably similar to the Difference Principle. Hayek also engaged in worst-case scenario theorising when considering the relative merits of different political regimes (Farrant and Crampton, 2008).

\section{Rawls' Consequentialist Egalitarianism}

Rawls' own justifications for a focus on the least advantaged emphasise the practical and are arguably concerned with something like robustness. An intrinsic pursuit of welfare equality is absent from Rawls' reasons for being concerned with equality, although there is a 'deontic' aspect of Rawls' egalitarianism grounded in the notion of fair procedures (O’Neill, 2008, pp.122-3).

Rawls' egalitarian commitment is grounded on substantially empirical concerns about the way societies work and the relationship between inequality and more widely accepted bad outcomes. His first reason is an aversion to poverty: 'it seems wrong that some or much of society should be amply provided for, while many ... suffer hardship, not to mention hunger and treatable illness' (Rawls, 2001, p.130). His second and fourth reasons both address essentially political economic concerns: that economic and social inequalities can allow 'a few ... to enact a system of law and property that ensures their dominant position in the economy as a whole' (Rawls, 2001, p.131); and that competitive markets and elections can be unduly influenced by wealthy individuals. Crucially, these are highlighted as harmful effects of economic and social inequality ('experienced as a bad thing'), making them instrumental reasons for avoiding inequality.

Rawls' third point comes closest to addressing economic inequality as intrinsically problematic: 'the widespread attitudes of deference and servility' imposed on the less well-off and 'a will to dominate and arrogance' encouraged in the better off. He sees this as inevitably engendered by some levels of economic inequality. These outcomes too are a threat to a society of formally free and equal people. Note the reasonable, but empirical, presumption that people will not respect each other as equal citizens in the presence of substantial material inequality. Rawls does not assume away the character defects of envy and contempt for those in substantially different circumstances. He wants to address them.

Equal citizenship is a demand of justice. Material equality is important as a necessary condition for guaranteeing equal citizenship. In this sense, Rawls' egalitarianism draws much of its strength from the widely accepted need to disperse power to maintain a liberal order. Similar to Montesquieu's doctrine of the separation of powers to limit arbitrary government, Rawls' theory is a separation of wealth to prevent political and social power being centralised 
and used for the interest of the few rather than for the common good (cf. Reiman, 2014, p.22).

Rawls' support for substantive equality is grounded not in an abstract moral commitment but in the practical concerns of political economy. For him, the status of free citizens lacks stability in the absence of the wide dispersion of wealth. This egalitarian commitment informs Rawls' two principles of justice. Arguably, it is the Liberty Principle that presents equality with greater stringency. It requires that an equal set of basic rights and liberties be available to all. The second principle, on the other hand, explains conditions under which limited socio-economic inequalities might be permitted: that they are attached to positions and offices available under fair equality of opportunity to all, and that these inequalities are to the advantage of the least well-off in society.

\section{EXPLORING COMMON GROUND}

This common ground represents the possibility of combining a Rawlsian normative standpoint with an RPE approach to evaluating institutions. This approach has several advantages. First, it re-articulates the value of constitutional theorising, emphasising the epistemic properties of widely accepted rules of the game and how they permit widespread social cooperation. Second, it defends Rawls' sometimes criticised division between institutions that make up the basic structure of society and individuals acting within civil society. Third, it takes contractarian theorising beyond the original position, and shows how everyday politics of exchange can produce beneficial and just outcomes given a sound institutional framework. Fourth, it reconciles a Rawlsian account of political regimes with the polycentric institutions that arguably help to sustain real liberal democratic regimes. Finally, the combination of RPE and Rawlsian concerns with inequality readily suggests a new regime type, a 'robust property-owning democracy', an adaption of Rawls' preferred regime which is potentially more stable in some real-world conditions. This is a novel regime type that instantiates Rawlsian commitments through neoliberal social justice.

From a different angle, this book contributes to ongoing attempts to reconcile Hayekian social theory with institutions aiming at social justice (Cowen, 2020b). Gamble (2006) argues that Hayek's unique contribution to social theory is his theory of knowledge, describing it as 'a thread which runs through almost all his work'. The problem is that 'Hayek's originality has never been properly appreciated beyond a relatively small circle, partly because Hayek continues to be read through ideological spectacles' (2006, p.112). I make significant use of Hayek's epistemic approach to economic theory. On the other hand, Hayek's political theory informs, but does not constrain, my approach to analysing the public policy implications of the knowledge problem. This 
means that I can suggest some configurations of welfare-state capitalism (WSC), and potentially more radically egalitarian forms of social democracy, that may turn out to be robust when facing knowledge and incentive problems.

\section{SUMMARY}

The arc of this book is as follows. I begin by applying RPE to the problem of distributive justice in the heights of ideal theory. I then take a step down to a mid-point of constitutional theorising and the implications of social morality outside the circumstances of justice. Finally, I descend to the depths of public policy and steps towards better political settlements. At each stage, I discuss the implications of distinguishing the realistic social conditions of imperfect knowledge and self-interested behaviour for the Rawlsian framework.

In Part I, I argue that institutions matter even in ideal theory. I defend a Rawlsian emphasis on the basic structure as a site of justice, rather than the demands of other philosophical perspectives that the site be grounded in personal conduct and behaviour in wider civil society. Some argue that a Rawlsian focus on institutions as the site of justice is too narrow and assumes that individuals themselves cannot be morally motivated to behave in a socially cooperative way. This means that Rawlsian incentive justifications for the Difference Principle are illegitimate compromises for an ideal theory of justice.

I show that there are scenarios where people of extraordinary goodwill are capable of producing bad social outcomes by discussing the problem of 'the Gift of Magi' as a mirror image of the prisoners' dilemma. In some such cases, stronger forms of altruism could cause worse welfare outcomes than weaker forms of altruism in a way that parallels coordination problems when assuming self-interest. Goodwill is not enough to generate attractive social outcomes, if the institutions are not present to translate goodwill into effective social cooperation. Imperfect knowledge and bounded rationality are natural features of human beings linked to the same biological limitations that prevent us from sprouting wings and flying like angels. Dispersed knowledge is a problem that needs to be solved even if we idealise away morally blameworthy features of human behaviour.

In Part II, I turn to the character of the institutions that have epistemic characteristics to support widespread social cooperation. I consider Rawls' claim that his theory is compatible with both private-property and socialist institutions. For reasons that parallel Rawls' justification for civic liberalism in the political sphere (the burdens of judgement), some private-property market institutions are necessary in the economic sphere. These 'burdens of knowledge' are problems of calculation, discovery and subjectivity. Theories of non-market alternative economic institutions assume that there is a given range 
of potential goods to be produced with a given pool of resources. They also rely on individuals having objective observable capacities and desires as well as tolerances for certain kinds of work. In fact, many resources and production processes must be discovered. Since many demands on resources are rivalrous, including between consumption and production, people require a mechanism through which they can choose to forego some forms of consumption in order to save them for alternative uses of necessarily uncertain value. No conceivable market socialist regime, which retains a rigid distinction between the allocation and distribution function of markets, can supply such a mechanism. Any feasible regime will contain some private-property markets.

In Part III, I begin to introduce incentive and compliance problems alongside the knowledge problem at the level of constitutional theorising. I discuss how economic institutions should fit into a wider political framework to argue for some constitutional protections of economic liberty. I discuss the role of market failure in Rawls' justification of extensive government control over the economy. Market failures are when economic actors do not converge on Pareto-efficient outcomes. In principle, such outcomes could be improved by government intervention. The classic market failure models that Rawls uses to illustrate his case assume that economic actors are narrowly self-interested. However, the actors in Rawls' political sphere are assumed to act with a sense of justice. A more symmetrical approach that rejects such a strict normative distinction between market and political behaviour is the more realistic but leaves the challenge of figuring out where the principles of justice could be agreed and pursued.

To resolve this impasse, I propose a new perspective, the constitutional point of view, which is the way that a judicious spectator evaluates the performance of rules that partial actors are required to follow. Alongside the more familiar moral point of view, adopting such a view allows agents engaged in public reason to establish what rules and constraints within both economic and political spheres would be commendable, given the overriding aim of achieving justice as fairness. Some constitutional constraints on both bureaucratic and democratic interventions into economic activity are commendable from this perspective.

In Part IV, I explore whether some economic liberties should be part of the basic liberties that Rawls gives priority in public decision-making because they contribute to the development of citizens' essential moral powers. Rawls explains that his theory applies to the circumstances of justice, defined as a position of moderate scarcity and reasonable pluralism of values. The circumstances of justice could only obtain in a community with some institutions capable of coordinating cooperative economic activity. These likely have the form of market institutions because more hierarchically ordered schemes of cooperation could not produce people capable of conceiving of each other as 
free and equal citizens. Some economic liberties are plausibly pre-conditions for the circumstances of justice. I show that economic liberties should subsequently be included in a scheme of basic liberties because economic activity is an important site for the development of Rawls' proposed two moral powers, a sense of justice and a capacity for a conception of the good. This leaves political communities with the power to regulate basic economic liberties to ensure that their fair value is guaranteed to all citizens, but not to abolish or deliberately constrain them.

In Part V, I outline the implications of RPE for attempts to establish a POD. I look at whether POD can be said to constitute an alternative to WSC. Definitions distinguishing the two ideas hinge on a broadly Marxian conceptualisation of capitalism, as necessarily a class-divided society. If we define capitalism more straightforwardly as a society with substantial individual liberties to own productive assets, engage in trade, and work for wages, the two concepts are not as easily distinguished, to the point that it would be hard to recognise when a society was a POD rather than a WSC.

Given this context, I evaluate the high liberal approach to POD which proposes a systematic distribution of capital assets which can allegedly take place at little or no loss in terms of investment or wealth accumulation. I argue that productive property does not put itself to use. It must be configured to yield a profit that is subject to risk and radical uncertainty. Entrepreneurial earnings require organisation, planning, effort, time and talent just as other forms of work. This mechanism is inhibited by substantial taxation in a similar fashion to income taxation. While some capital taxation is feasible, it is rightly considered to come at significant costs to investment. With these limitations, I propose a different regime, a robust POD, which uses alternative mechanisms to increase the dispersion of wealth, including some that were proposed by Meade himself: tax efficient savings schemes that provide easy access to equity and bond markets, and support for home ownership.

Concluding, I explain how many of the assumptions of my critique are already well-established in liberal political theory and in the Rawlsian framework itself. This has the advantage of engaging with shared problems within liberal political theory. It allows me to extend, rather than critique, the policy implications of Rawls' theory of justice. I explain that there is still more theory to do, especially on questions of global justice and ensuring compliance. Overall, however, I show that my novel proposals aiming at neoliberal social justice are both an attractive and realistic instantiation of Rawls' conception of justice as fairness. 


\section{REFERENCES}

Acemoglu, D. and Robinson, J. (2015) 'The Rise and Decline of General Laws of Capitalism'. Journal of Economic Perspectives. 29 (1), 3-28.

Alves, A.A. and Meadowcroft, J. (2013) 'Hayek's Slippery Slope, the Stability of the Mixed Economy and the Dynamics of Rent Seeking: The Mixed Economy and Rent Seeking'. Political Studies. Available from: http://doi.wiley.com/10.1111/1467 -9248.12043 (accessed 2 January 2014).

Baker, D. (2015) The Upward Redistribution of Income: Are Rents the Story? Available from: http://cepr.net/documents/working-paper-upward-distribution-income-rents.pdf (accessed 4 December 2020).

Barry, B. (1973) The Liberal Theory of Justice: A Critical Examination of the Principal Doctrines in A Theory of Justice by John Rawls. Oxford: Clarendon Press.

Berggren, N. (2013) James M. Buchanan Jr. Econ Journal Watch. 10 (3), 292-9.

Brennan, J. (2016) Against Democracy. Princeton, NJ: Princeton University Press.

Buchanan, J.M. (1964) 'What Should Economists Do?' Southern Economic Journal. $30(3), 213$.

Buchanan, J.M. (1976) 'The Justice of Natural Liberty'. The Journal of Legal Studies. $5(1), 1-16$.

Buchanan, J.M. (1999) [1969] Cost and Choice: An Inquiry in Economic Theory. Collected works of James M. Buchanan v. 6. Indianapolis, IN: Liberty Fund.

Buchanan, J.M. (2000) [1975] The Limits of Liberty: Between Anarchy and Leviathan. Collected works of James M. Buchanan v. 7. Indianapolis, IN: Liberty Fund.

Buchanan, J.M. (2001) Moral Science and Moral Order. Collected works of James M. Buchanan v. 17. Indianapolis, IN: Liberty Fund.

Buchanan, J.M. and Congleton, R.D. (2003) [1998] Politics by Principle, Not Interest: Toward Nondiscriminatory Democracy. Indianapolis, IN: Liberty Fund.

Buchanan, J.M. and Faith, R.L. (1980) 'Subjective Elements in Rawlsian Contractual Agreement on Distributional Rules'. Economic Inquiry. 18 (1), 23-38.

Buchanan, J.M. and Tullock, G. (1999) [1962] The Calculus of Consent: Logical Foundations of Constitutional Democracy. Collected works of James M. Buchanan v. 3. Indianapolis, IN: Liberty Fund.

Chambers, S. (2012) 'Justice or Legitimacy, Barricades or Public Reason?', in Martin O'Neill and Thad Williamson (eds), Property-owning Democracy: Rawls and Beyond. Malden, MA: Wiley-Blackwell. pp. 17-32.

Cowen, N. (2016) 'Introduction: Symposium on Robust Political Economy'. Critical Review. 28 (3-4), 420-39.

Cowen, N. (2017) 'Why Be Robust? The Contribution of Market Process Theory to the Robust Political Economy Research Program', in Peter J. Boettke, C.J. Coyne and V.H. Storr (eds), Interdisciplinary Studies of the Market Order: New Applications of Market Process Theory. London: Rowman and Littlefield International. pp. 63-85.

Cowen, N. (2018) 'Robust Against Whom?', in Steven Horwitz (ed.), Austrian Economics: The Next Generation. Advances in Austrian Economics. Bingley, UK: Emerald Publishing. pp. 91-111. Available from: https://doi.org/10.1108/S1529 -213420180000023008 (accessed 14 April 2020).

Cowen, N. (2020a) 'Hayek: Postatomic Liberal', in Gene Callahan and Kenneth B. McIntyre (eds), Critics of Enlightenment Rationalism. Cham: Springer International Publishing. pp. 179-92. Available from: http://link.springer.com/10.1007/978-3-030 -42599-9_12 (accessed 1 June 2020). 
Cowen, N. (2020b) 'Hayek's Appreciative Theory and Social Justice'. Cosmos + Taxis. $7(5-6), 10-19$.

Cowen, N. (2021) 'Basic Economic Liberties: John Rawls and Adam Smith Reconciled'. The Independent Review. Available from: https://papers.ssrn.com/sol3/papers.cfm ?abstract_id=3596764 (accessed 4 December 2020).

D'Amico, D. (2015) 'Spontaneous Order', in Christopher J. Coyne and Peter J. Boettke (eds), The Oxford Handbook of Austrian Economics. Oxford University Press. Available from: http://www.oxfordhandbooks.com/view/10.1093/oxfordhb/ 9780199811762.001.0001/oxfordhb-9780199811762-e-6 (accessed 22 March 2016).

Daniels, N. (1979) 'Wide Reflective Equilibrium and Theory Acceptance in Ethics'. The Journal of Philosophy. 76 (5), 256-82.

Edmundson, W.A. (2017) John Rawls: Reticent Socialist. Cambridge; New York: Cambridge University Press.

Epstein, R.A. (1995) Simple Rules for a Complex World. Cambridge, MA: Harvard University Press.

Evans, A.J. (2010) 'Only Individuals Choose', in Peter Boettke (ed.), Handbook on Contemporary Austrian Economics. Cheltenham, UK and Northampton, MA, USA: Edward Elgar Publishing. pp. 4-13. Available from: http://www.elgaronline.com/ view/9781847204110.xml (accessed 10 March 2016).

Farrant, A. and Crampton, E. (2008) 'Robust Analytical Egalitarianism: Worst-case Political Economy and the Socialist Calculation Debate', in Sandra Peart and David M. Levy (eds), The Street Porter and the Philosopher: Conversations on Analytical Egalitarianism. Ann Arbor, MI: University of Michigan Press. pp. 108-32.

Freeman, S. (2001) 'Illiberal Libertarians: Why Libertarianism Is Not a Liberal View'. Philosophy \& Public Affairs. 30 (2), 105-51.

Gamble, A. (2006) 'Hayek on Knowledge, Economics, and Society', in Edward Feser (ed.), The Cambridge Companion to Hayek. Cambridge companions. Cambridge; New York: Cambridge University Press. pp. 110-31.

Garnett, R.F. (ed.) (2014) Commerce and Community: Ecologies of Social Cooperation. Economics as social theory. Abingdon, Oxon; New York: Routledge.

Gaus, G.F. (2010) 'Coercion, Ownership, and the Redistributive State: Justificatory Liberalism's Classical Tilt'. Social Philosophy and Policy. 27 (01), 233.

Gauthier, D.P. (1986) Morals by Agreement. Oxford: Clarendon Press.

Geuss, R. (2008) Philosophy and Real Politics. Princeton, NJ: Princeton University Press.

Hayek, F.A. von (1945) 'The Use of Knowledge in Society'. American Economic Review. 35 (4), 519-30.

Hayek, F.A. von (1976) Law, Legislation and Liberty: A New Statement of the Liberal Principles of Justice and Political Economy. 2, the Mirage of Social Justice. Chicago, IL: University of Chicago Press.

Hayek, F.A. von (2011) [1960] The Constitution of Liberty: The Definitive Edition. Collected works of F.A. Hayek v. 17. Ronald Hamowy (ed.). Chicago, IL: University of Chicago Press.

Hayek, F.A. von (2014) [1968] 'Competition as a Discovery Procedure', in Bruce Caldwell (ed.), The Market and Other Orders. Chicago, IL: University of Chicago Press. pp. 304-13.

Hills, J., Bastagli, F., Cowell, F., Glennerster, H., Karagiannaki, E. and McKnight, A. (2013) Wealth in the UK: Distribution, Accumulation, and Policy. Oxford: Oxford University Press. Available from: http://www.oxfordscholarship.com/view/ 
10.1093/acprof:oso/9780199678303.001.0001/acprof-9780199678303 (accessed 3 December 2015).

Kirzner, I.M. (2013) [1973] Competition and Entrepreneurship. Collected works of Israel M. Kirzner. Peter J. Boettke and Frédéric E. Sautet (eds). Indianapolis, IN: Liberty Fund.

Krouse, R. and McPherson, M.S. (1988) 'Capitalism, "Property-owning democracy," and the Welfare State', in Amy Gutmann (ed.), Democracy and the Welfare State. Studies from the Project on the Federal Social Role. Princeton, NJ: Princeton University Press. pp. 79-106.

Kukathas, C. and Pettit, P. (1990) Rawls: A Theory of Justice and Its Critics. Cambridge: Polity.

Lavoie, D. (1986) 'The Market as a Procedure for Discovery and Conveyance of Inarticulate Knowledge'. Comparative Economic Studies. 28 (1), 1-19.

Lister, A. (2013) 'The "Mirage" of Social Justice: Hayek Against (and For) Rawls'. Critical Review. 25 (3-4), 409-44.

Meade, J.E. (1945) 'Mr. Lerner on "The Economics of Control"'. The Economic Journal. 55 (217), 47.

Meade, J.E. (2012) [1964] Efficiency, Equality and the Ownership of Property. Abingdon, Oxon; New York: Routledge.

Meadowcroft, J. (2014) 'Exchange, Unanimity and Consent: A Defence of the Public Choice Account of Power'. Public Choice. 158 (1-2), 85-100.

Menger, C. (1985) [1883] Investigations into the Method of the Social Sciences, with Special Reference to Economics. The Institute for Humane Studies series in economic theory. Louis Schneider (ed.). New York: New York University Press.

Mises, L. von (1998) [1949] Human Action: A Treatise on Economics. Scholar's edn. Auburn, AL: Ludwig Von Mises Institute.

Novak, M. (2018) Inequality: An Entangled Political Economy Perspective. Palgrave studies in classical liberalism. Cham, Switzerland: Palgrave Macmillan.

O’Neill, M. (2008) 'What Should Egalitarians Believe?' Philosophy \& Public Affairs. $36(2), 119-56$.

O’Neill, M. and Williamson, T. (eds) (2012) Property-owning Democracy: Rawls and Beyond. Malden, MA: Wiley-Blackwell.

Parijs, P. van (2011) Just Democracy: The Rawls-Machiavelli Programme. ECPR Press essays. London: ECPR Press.

Pennington, M. (2011) Robust Political Economy: Classical Liberalism and the Future of Public Policy. New thinking in political economy. Cheltenham, UK and Northampton, MA, USA: Edward Elgar Publishing.

Pennington, M. (2015) 'Constitutional Political Economy and Austrian Economics', in Peter J. Boettke and Christopher J. Coyne (eds), The Oxford Handbook of Austrian Economics. Oxford; New York: Oxford University Press. pp. 464-90.

Piketty, T. (2014) Capital in the Twenty-first Century. Cambridge, MA: The Belknap Press of Harvard University Press.

Rawls, J. (1974) 'Some Reasons for the Maximin Criterion'. The American Economic Review. 64 (2), 141-6.

Rawls, J. (1999) [1971] A Theory of Justice. Cambridge, MA: Belknap Press of Harvard University Press.

Rawls, J. (2001) Justice as Fairness: A Restatement. Cambridge, MA: Harvard University Press.

Rawls, J. (2005) [1993] Political Liberalism. Columbia classics in philosophy. Expanded edn. New York: Columbia University Press. 
Reiman, J.H. (2014) As Free and as Just as Possible: The Theory of Marxian Liberalism. Chichester: Wiley-Blackwell.

Sabl, A. (2017) 'Realist Liberalism: An Agenda'. Critical Review of International Social and Political Philosophy. 20 (3), 366-84.

Saez, E. (2012) 'Striking It Richer: The Evolution of Top Incomes in the United States (Updated with 2009 and 2010 Estimates)'. Pathways Magazine. Available from: http://elsa.berkeley.edu/ saez/saez-UStopincomes-2010.pdf (accessed 7 February 2013).

Schmidtz, D. (2005) 'History and Pattern'. Social Philosophy and Policy. 22 (01), $148-77$.

Schmidtz, D. (2016) 'A Realistic Political Ideal'. Social Philosophy and Policy. 33 (1-2), 1-10.

Shapiro, D. (1991) 'Free Speech, Free Exchange, and Rawlsian Liberalism'. Social Theory and Practice. 47-68.

Sleat, M. (2016) 'Realism, Liberalism and Non-ideal Theory Or, Are there Two Ways to do Realistic Political Theory?' Political Studies. 64 (1), 27-41.

Taylor, B. and Crampton, E. (2009) 'Anarchy, Preferences, and Robust Political Economy'. Available at SSRN 1340779. Available from: http://papers.ssrn.com/ sol3/papers.cfm?abstract_id=1340779 (accessed 28 October 2015).

Thomas, A. (2015) 'Rawls and Political Realism: Realistic Utopianism or Judgement in Bad Faith?' European Journal of Political Theory. Available from: http://ept .sagepub.com/cgi/doi/10.1177/1474885115578970 (accessed 2 January 2016).

Tomasi, J. (2012) Free Market Fairness. Princeton, NJ: Princeton University Press.

Trantidis, A. and Cowen, N. (2020) 'Hayek versus Trump: The Radical Right's Road to Serfdom'. Polity. 52 (2), 159-88.

Zingales, L. (2012) A Capitalism for the People: Recapturing the Lost Genius of American Prosperity. New York: Basic Books.

Zwolinski, M. (2008) 'The Separateness of Persons and Liberal Theory'. The Journal of Value Inquiry. 42 (2), 147-65. 